\title{
Care management for the hospitalized child with chronic cancer pain: intervening conditions
}

\author{
Gerenciamento do cuidado à criança hospitalizada com dor oncológica crônica: condições intervenientes \\ Gerencia del cuidado al niño hospitalizado con dolor em cáncer crónico: condiciones intervenientes
}

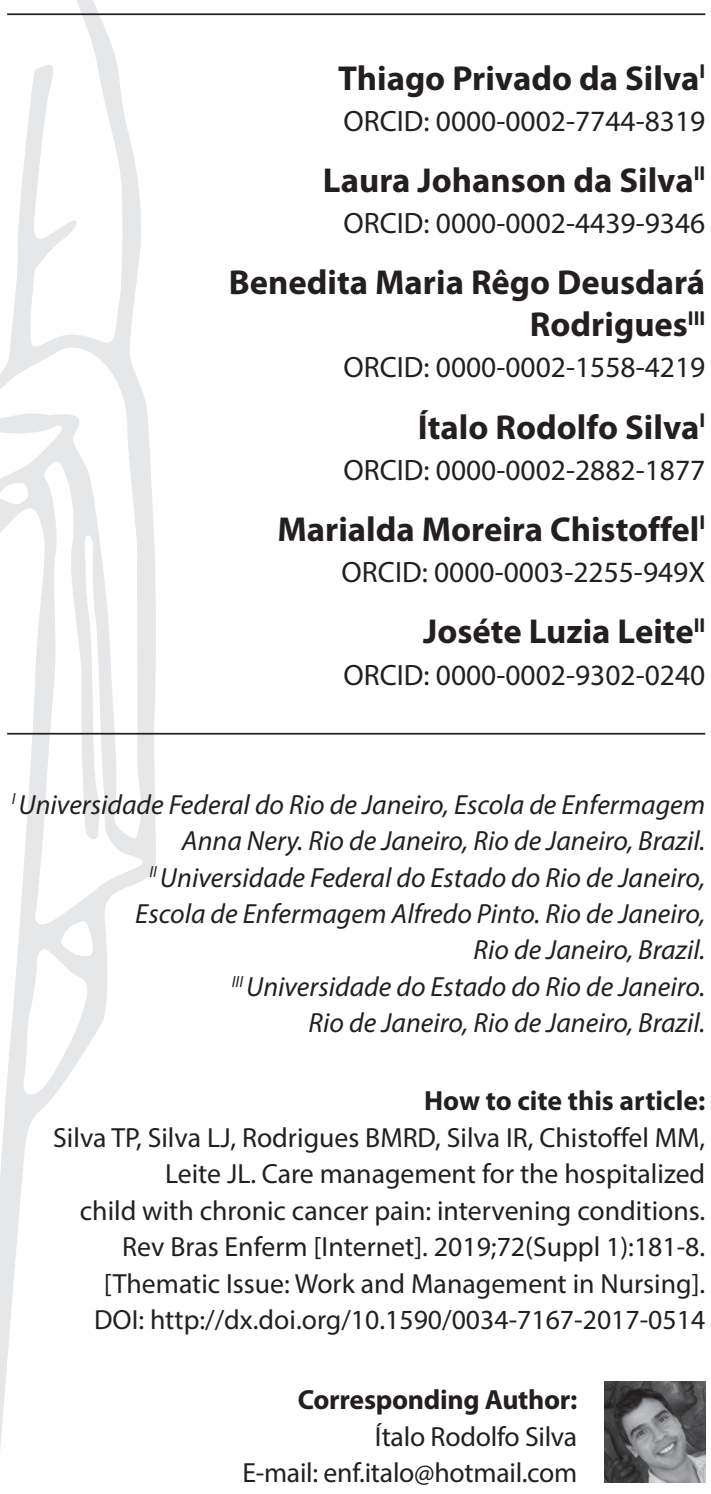

Submission: $07-31-2017$

Approval: 04-26-2018

\begin{abstract}
Objective: To understand the intervening conditions of care management for the hospitalized child with chronic cancer pain. Method: Qualitative research, anchored in the methodological and theoretical frameworks, respectively, Grounded Theory and Complex Thinking. The semi-structured interview and non-participant observation were used to collect the data. Twenty-one health professionals, organized in three sample groups: nurses; nursing technicians; and professionals of the multiprofessional health staff. Results: They emerged as intervening conditions of care management: human resources and materials, teamwork, absenteeism, professional relocation, professional qualification, family, playful, dialogue, empathy and caring relationship. Conclusion: It was understood as limiting conditions for care management: deficits of human resources and materials, absenteeism, ineffective teamwork, professional relocation, and insufficient professional qualification. On the other hand, they were presented as facilitating conditions: adequate professional knowledge, effective teamwork, dialogue, empathy, playful and affective relationship with the child.

Descriptors: Practice Management; Hospitalized Child; Chronic Pain; Pediatric Nursing; Nursing Care.
\end{abstract}

\section{RESUMO}

Objetivo: Compreender as condições intervenientes do gerenciamento do cuidado à criança hospitalizada com dor oncológica crônica. Método: Pesquisa qualitativa, ancorada nos referenciais metodológico e teórico, respectivamente, Teoria Fundamentada em Dados e Pensamento Complexo. A entrevista semiestruturada e a observação não participante foram utilizadas para coletar os dados. Participaram da pesquisa 21 profissionais de saúde, organizados em três grupos amostrais: enfermeiros; técnicos de enfermagem; e profissionais da equipe multiprofissional de saúde. Resultados: Emergiram como condições intervenientes do gerenciamento do cuidado: recursos humanos e materiais, trabalho em equipe, absenteísmo, remanejamento profissional, qualificação profissional, familiares, lúdico, diálogo, empatia e relação de carinho. Conclusão: Compreendeu-se como condições limitadoras para o gerenciamento do cuidado: déficit de recursos humanos e materiais, absenteísmo, trabalho em equipe ineficaz, remanejamento profissional, e qualificação profissional insuficiente. Por outro lado, foram apresentadas como condições facilitadoras: conhecimento profissional adequado, trabalho em equipe eficaz, diálogo, empatia, lúdico e relação afetiva com a criança.

Descritores: Gerenciamento da Prática Profissional; Criança Hospitalizada; Dor Crônica; Enfermagem Pediátrica; Cuidados de Enfermagem.

\section{RESUMEN}

Objetivo: Comprender las condiciones intervinientes de la gestión del cuidado al niño hospitalizado con dolor em cáncer crónico. Método: Investigación cualitativa, anclada en los referenciales metodológico y teórico, respectivamente, Teoría Fundamentada en Datos y Pensamiento Complejo. La entrevista semiestructurada y la observación no participante fueron utilizadas para recoger los datos. Participaron de la investigación 21 profesionales de salud, organizados en tres grupos muestrales: enfermeros; técnicos de enfermería; y profesionales del equipo multiprofesional de salud. Resultados: Emergieron como condiciones intervinientes de la gestión del cuidado: recursos humanos y materiales, trabajo en equipo, absentismo, reubicación profesional, cualificación profesional, familiares, lúdico, diálogo, empatía y relación de cariño. Conclusión: Se entendió como condiciones limitadoras para la gestión del cuidado: déficit de recursos humanos y materiales, absentismo, trabajo en equipo ineficaz, reubicación profesional, y calificación profesional insuficiente. Por otro lado, fueron presentadas como condiciones facilitadoras: conocimiento profesional adecuado, trabajo en equipo eficaz, diálogo, empatía, lúdico y relación afectiva con el niño.

Descriptores: Gestión de la Práctica Profesional; Niños Hospitalizados; Dolor Crónico; Enfermería Pediátrica; Cuidados de Enfermería. 


\section{INTRODUCTION}

Pain, among other symptoms, is more common in the child with cancer, being also the main cause of suffering ${ }^{(1-3)}$. In developing countries, where many children have advanced cancer and few have access to effective treatment, cancer pain is related to the progression of the disease. In developed countries, cancer pain is related to the treatment and to the diagnostic and therapeutic procedures performed in the child(4).

Cancer pain can be either acute or chronic. Acute pain is usually self-limiting and arises as a result of a tissue injury that tends to disappear when the wound heals. Chronic pain, on the other hand, is continuous (persistent) or recurrent (episodic) and goes beyond the expected cure time ( $>3$ to 6 months) ${ }^{(4-5)}$.

The literature ${ }^{(4)}$ emphasizes that the presence of chronic pain in children with chronic disease, for example cancer, can adversely affect various aspects of childhood life, including physical activity, school attendance, sleep patterns, family interaction, social relations, humor, among other aspects. In this perspective, a study ${ }^{(6)}$ found that children with chronic cancer presented difficulties in the extracurricular (16.7\%), domestic (14.6\%), social (12.6\%), sleep ) and academic (12.5\%).

Thus, it is necessary to recognize chronic cancer pain as a complex phenomenon, since it is, by its nature, a multidimensional condition constituted by the sensory, cognitive, affective, behavioral and physiological components ${ }^{(4)}$. From this perspective, the literature ${ }^{(7)}$ presents the concept of "total pain", which refers to the pain of patients with advanced disease. Under the lens of "total pain", it is understood that human suffering due to pain demands a look at its multiple dimensions, namely: physical, spiritual, social and psychological, that is, the pain of a patient with advanced disease does not is restricted to its physical dimension, but involves other aspects that need to be considered in care management.

For this reason, the framework of complexity was appropriate to guide this research, since it provides a contextualized view for the study of chronic cancer pain in childhood, considering, at this juncture, movements of order, disorder, interactions and organizations $^{(8)}$ throughout the process of care management. Thus, it is understood that care management for the hospitalized child with chronic cancer pain implies dealing with different levels of order and disorder that emerge from interpersonal relationships, as well as from the organizational context of care. It is the dynamics of these elements that makes a condition be considered as limiting and/or facilitating the practice of care management.

In this regard, it is observed that the literature ${ }^{(6,9-11)}$ on the subject on the screen has focused mainly on the evaluation and management of chronic cancer pain in the child, pointing out important professional barriers in performing both processes. In this direction, the present research has originality when addressing the limiting and/or facilitating conditions that permeate the care management for the hospitalized child with chronic cancer pain, under the theoretical perspective of the dialogic principle of complexity, relying on the Grounded Theory method, considering, in this particular, not only the actions of evaluation and management of pain, but also the relational and organizational context of care.
In this sense, it was defined as the objective of this research to understand the intervening conditions of care management for the hospitalized child with chronic cancer pain. It is hoped that the results favor an understanding of the dialogical relationship between order and disorder, thus revealing which conditions are considered to be facilitating and/or limiting the management process of care.

\section{OBJECTIVE}

To understand the intervening conditions of care management for the hospitalized child with chronic cancer pain.

\section{METHOD}

\section{Ethical aspects}

Data collection was initiated after approval of the research by the Research Ethics Committee of the participating institution, Hemorio - Hemorio - Instituto Estadual de Hematologia Arthur de Siqueira Cavalcanti - Government of the Rio de Janeiro State/State Health Office and by the Ethics Committee in Research of the Escola de Enfermagem Anna Nery EEAN/UFRJ. All the participants signed the Informed Consent Term.

In accordance with the recommendations of Resolution 466/2012 of the National Health Council (Conselho Nacional de Saúde) of the Ministry of Health, to maintain the anonymity of the research participants, the nurses' speeches are identified by the letter $\mathrm{N}$, the nursing technicians by the letter NT, the doctors by the letter $D$, the pharmacist by the letters PC, the psychologist by the letter PS, the physiotherapists by the letters $\mathrm{PH}$ and the social worker by the letters SW. All are followed by a figure that refers to the order of the interviews in each sample group (ex: N1, NT1, D1).

\section{Theoretical-methodological framework and Type of study}

A qualitative research, of the explanatory type, guided by the Grounded Theory, as well as by the theoretical framework of the Complex Thinking from the perspective of Edgar Morin. The choice of Grounded Theory as a method of qualitative research is justified by the possibility of understanding the phenomenon investigated, from the elaboration of densely theorized concepts, which are capable of revealing phenomena underlying the object of research, thus favoring the understanding and explanation of the meanings that guide social relations ${ }^{(12)}$. The Complex Thinking was used as theoretical support, aiming at a contextualized, dynamic, objective and subjective understanding about the conditions that permeate the care management. For this purpose, concepts and principles were used in the analysis and discussion of the results, among which it is necessary to emphasize in this article the dialogic one, which is based on the complementary relation between the order and the disorder.

\section{Methodological procedures}

The present research was carried out with health professionals at the Pediatric Inpatient Unit (PIU) of a hospital that presents itself as 
a reference for the treatment of hematological diseases, located in Rio de Janeiro, Brazil. The Pediatric Inpatient Unit contains 13 beds, one of which is intended for the child in contact precaution. In this context, the main medical diagnoses of hospitalized children are: leukemia, lymphoma and sickle cell diseases. The nursing team is composed of 22 nursing technicians, one nursing assistant and seven nurses. Two nurses, three nursing technicians and a nursing assistant work in the morning being responsible for the stock of materials and other inputs of the unit. Three nursing technicians and a nurse work in the afternoon period, as well as on weekends and holidays.

The participants of the research were defined using the theoretical sampling feature ${ }^{(12)}$, whose objective is to find people, places or facts that increase the possibility of discovering variations between the concepts and of making the categories dense in terms of their properties and dimensions. Thus, they were organized into three sample groups, the first being composed of seven nurses; the second by seven nursing technicians; and the third and final group of seven other health professionals, two doctors, two physiotherapists, a social worker, a psychologist and a pharmacist. All participants met the inclusion criteria: having at least one year of experience in the care of the child with cancer and having the same period of professional attachment to the institution. Excluded were health professionals who were on leave or vacation.

Data were collected between August 2014 and June 2015 through a semi-structured interview and non-participant observation. The interviews were initiated with the following guiding questions: What conditions do you consider as facilitating and/ or limiting the practice of care management to the hospitalized child with chronic cancer pain? How do such conditions influence your care practice? It should be emphasized that, initially, the research proposal focused only on nurses' care experiences. However, from the collection and analysis of the data, carried out concomitantly and guided by the comparative analysis ${ }^{(12)}$, the following assumption emerged: Teamwork conditions the management of the care performed by the nurse, presenting aspects that facilitate and/or complicate this process. For this reason, the data collection involved other health professionals in order to understand how this phenomenon happens.

The non-participant observation was performed on five occasions, during the daytime period, after the participants' discourse analysis, and totaled 54 hours. The contents were recorded in observation notes. It should be emphasized that the finalization of the data collection in each sample group was determined by the theoretical saturation, at which point the new data collected were no longer changing in consistency and theoretical density the concepts constructed ${ }^{(12)}$.

As discussed in the Grounded Theory, data are collected and concomitantly analyzed. Data were analyzed by means of the following coding steps: open, axial and selective. In the "open" coding, the data were coded line by line, generating the preliminary codes which, in turn, after being grouped by similarities, gave rise to the conceptual codes. The grouping of conceptual codes by similarities gave rise to categories and subcategories.

In the "axial" coding, the categories were related among themselves and between their subcategories, in order to determine their properties and dimensions. At the moment of the analysis, the analytical tool called the Paradigmatic Model ${ }^{(12)}$ made it possible to gather/sort/integrate the previously elaborated categories, favoring the emergence of the central research phenomenon, carried out in the selective coding stage. In this last phase, the validation of the results ${ }^{(12)}$, which occurred in September and October 2016, was also developed, counting on the participation of five validators, three Nursing researchers with expertise in Grounded Theory and/ or research in the area of Nursing Management and two nursing assistants who composed the first sample group of the present research. It should be noted that the selection of validators occurred for convenience. In addition to the coding process, memos and diagrams were used to aid in the theoretical analysis of the data.

\section{RESULTS}

Of the total of 21 participants in the survey, only one was male and composed the first sample group. In this same group, the experience time in the care for the child with cancer ranged from one to 13 years. In the second sample group, considering the same variable, there was oscillation of one to two years. In the third sample group, the hematopediatrists presented experience ranging from three to five years. In this direction, physiotherapists, as well as the psychologist, presented experience of one year and six months in the care of the child with cancer, while the social worker said to present two years of performance in the same setting. It should be noted that the pharmaceutical company that participated in the study did not act directly in the care of the child with cancer, given their responsibility to manage the institution's pharmacy. However, she pointed out that for two years she has teamed with the health professionals of the Pediatric Inpatient Unit, subsidizing drugs capable of promoting the relief of chronic cancer pain.

From the analysis of the data, the central phenomenon emerged: Management of nursing care for hospitalized children with chronic cancer pain - an experience of several interactions. This phenomenon presents as an intervening condition the conceptual category entitled: Finding (Dis)Order in the Management Context of Care for the Child with Chronic Cancer Pain, which is constituted by two subcategories, namely: Listing Limiting Interventions for the Development of Care for the Child with Chronic Cancer Pain; and Punctuating Facilitating Interventions for the Development of Care for the Child with Chronic Cancer Pain.

In the subcategory Listing Limiting Interventions for the Development of Care for the Child with Chronic Cancer Pain, it was understood that the nursing professionals experience difficulties related to the quality and the deficit of material resources.

\section{Today, my biggest difficulty is with material resources. (N1)}

The lack of material is another thing that hinders [...] When you have the material, sometimes it isn't of good quality and this also makes it difficult. (NT3)

I think the lack of materials and equipment can be very difficult. I think this is paramount. It should have equipment enough to be used in the care. (NT5)

The following nurses' speech exposes how the quality of the material influences the nursing care provided to hospitalized children with cancer pain: 
Often, we have to stick to the children several times, causing unnecessary pain because the material isn't good (N2).

Nursing professionals also experience difficulties related to the pharmacological analgesia of chronic cancer pain, as explained below:

Often lack basic medications for pain control. Sometimes lacking morphine, missing tramal, lacking codeine which are medications for moderate to severe pain. (N2)

What is difficult is the question of inputs. Sometimes we don't have certain medications. (N5)

Sharing this same reality, the doctor reinforces experiencing difficulties in the pharmacological management of pain due to the lack of medication in the institution. In addition, it emphasizes the importance of the health professional always having access to medicines to provide the child with the relief of their pain.

We had a hard time at the institution. We had a period when we had no medication to do on the child. We didn't have a cetrolac, a venous tramal, a venous morphine. So you have a difficult time and you have to have all these options to be able to treat the pain and take the child out of suffering. (D1)

In addition to the mentioned disorders, nursing professionals experience and characterize absenteeism, relocation of professionals in the staff, as well as deficit of human resources of nursing, as limiting factors of care.

I face a lot of absenteeism, a lot of staff change. (N1)

I don't know why people are missing so much. I think this should be investigated, because professional deficit impairs the quality of care. (N6)

The relocation of the nursing team is something we don't like because we specialize to take care of children. I"s something that breaks our work a little. This makes us a little discouraged. (NT6)

These factors also hamper the management of the Pediatric Inpatient Unit, as the nurse:

Another thing that hinders is the lack of staff. Today I am with an outsider, who works with an adult and who doesn't know the routine of the sector. I am with less a technician who is experienced and this ends up undermining the management of the sector. (N5)

In the excerpts below, it is possible to understand the impact of these disorders on the practice of nursing care management.

We can't meet everyone. When they have two technicians and a nurse, we can't. Assistance is desired and this leads to delays in medication and mothers complain. (N3)

If I have a professional license and a vacation, this makes it difficult to get closer to the patients. I have to spend a quicker visit because I have to organize the technicians, I don't have time to chat, to be interacting. (N6)
Professional qualification is an important aspect for the care for hospitalized children with chronic cancer pain, and their insufficiency is a condition that negatively influences the practice of care, as exposed by the following professionals:

The unskilled professional can also make it difficult to assist. We perceive this by the way this professional acts. (NT5)

If you don't have a professional qualification that provides you knowing the medications, its main effects, how will you inform people who don't know? [...] I always have new medicines and I need to qualify myself to know if this new medicine really makes a difference in the life of this child. (PC3)

In the scope of teamwork, it was exposed that excessive collections and the lack of adequate communication are configured as limiting conditions of this work process.

I think that excessive charges can make it difficult for me to interact with the professionals in the staff. (N5)

What can disrupt is a professional not wanting to listen to the other, not having a communication, a dialogue. I think a good staff is the one that is well-oiled. (D2)

Lack of communication, lack of freedom to get to the doctor and talk about your prescription, hinders teamwork. (PC3)

Family members were considered to intervene in the practice of care for the hospitalized child with chronic cancer pain. The excerpts from the following testimonies denote this perspective:

What I realize in pediatrics is that if you can establish a good relationship with the mother, from the beginning, the thing flows well. Now, if she didn't like you very much, she didn't identify with you, it's an obstacle, it's difficult. (NT3)

Parents, while they are very much in our favor, they are also very against. They may try to manipulate the child and it is very important to consider our sense. (NT7)

Who will give the first meaning of illness and hospitalization to the child are the parents [...] my interaction with the child also depends on how the mother is passing on that meaning to her. (PS5)

In another angle, the subcategory Punctuating Facilitating Interventions for the Development of Child Care with Chronic CancerPain shows that professional qualification and teamwork are conditions that facilitate the management of care.

Teamwork is very important. It makes a lot of difference. When we work as a team things flow better. (SW7)

I think professional qualification is important. It makes a difference, at least for me [...] this prior knowledge already facilitates care [...] the treatment is very specific, so I think it makes a difference if you have a qualification. (N7)

The context in which child care is developed with chronic cancer pain should be welcoming and conducive to dialogue. 
When dealing with the pediatric setting, a caring relationship and the incorporation of the playful can intensify the interactive process and facilitate the accomplishment of the care.

I find games important because the kids are in a completely aggressive environment. The more relaxed it becomes, the easier it takes care. (D1)

I find the playful essential. It is very difficult for you to work with children without the playful. So with the games, they have a much better acceptance. (PH4)

Caring facilitates. When you come talking, playing with them, this increases the approach. (NT2)

Empathy was punctuated as a facilitating condition of the interpersonal relationships between the nursing professional and the relative, as revealed below:

If we put ourselves on the shoes of that [family member] person, we can have a better relationship her/him. (N3)

Nursing technicians have children and they put themselves on the family's shoes. I think this facilitates the development of care. (N6)

Based on the above, it was understood that care management is permeated by situations of order and disorder and that organizational, personal, professional and relational factors condition the planning and implementation of care in teamwork.

\section{DISCUSSION}

Managing care for the hospitalized child with chronic cancer pain implies experiencing a certain level of order and disorder. The notion of order (facilitating condition) includes regularities, stabilities, constancies, repetitions, invariances and determinations. On the other hand, disorder (limiting condition) involves agitations, dispersions, turbulences, irregularities, instabilities, accidents, accidents, noise, and errors in the different contexts of human society ${ }^{(8)}$. These two dimensions complement each other in the management of care, since the idea of disorder entails the need for new relational, organizational, new ways of achieving order, while the latter carries with it not only the idea of organization, as well as that of the disorder itself, because it recalls that uncertainties and unpredictability are inherent elements of the organizational context, thus revealing the need to establish strategies.

It was understood that care management for the hospitalized child with chronic cancer pain is complex, dynamic, unique and influenced by multiple conditions that favor or limit its implementation. Based on the results presented, nursing professionals, in their managerial practice of care, experience disorders related to the deficit and the quality of material resources available in the institution.

Regarding this fact, a study ${ }^{(13)}$ presented a similar result to the present research, pointing out the deficit of material resources in the hospital institution as a limiting factor of the nursing care management practice for the hospitalized child in chronic condition. In addition, the results of the present research show that the quality of material resources also influences nursing care delivery and the interactive process between the child and the health professional, while low quality material favors the repetition of procedures that cause pain and suffering, raising the child's level of stress, fear and anxiety.

In the present study, it was identified that health professionals experience disorders related to medication deficit, some considered indispensable for the management of chronic cancer pain. This situation promotes delays in medication administration, as well as episodes of interpersonal conflicts between the nursing professional and the family member. From this perspective, a research ${ }^{(14)}$ pointed out that problems in the organization and structure of the service are configured as limiting conditions for the promotion of integral care for the child with cancer, since they are sources of conflicts between the health professional and the institution.

It was understood that absenteeism, nursing team reassignment, and human resources deficit are disorders that are part of the care context investigated. These factors limit the care management for the hospitalized child with chronic cancer pain, since they can lead to work overload, professional demotivation and fragility of interprofessional relationships. Also, it was revealed that the same factors also make it difficult to manage the Pediatric Inpatient Unit.

It is understood that absenteeism can compromise interpersonal and interprofessional relationships, as well as influence the routine and quality of evaluation and management of chronic cancer pain. It is a condition that requires attention and multifocal views of nurses in the management of human resources in order to avoid their occurrence and attenuate their negative impacts on the quality of care.

It is stressed that the lack of staff and work overload are conditions that negatively influence the quality of care provided to children with pain ${ }^{(15)}$, thus generating unnecessary delays in the hospital discharge process, which prolongs the hospitalization of the child ${ }^{(16)}$

Allied to the above, the high turnover of staff in the nursing team also conditions teamwork, since it weakens the establishment of effective links. In this sense, a research ${ }^{(17)}$ reported that the high turnover of staff in the team is synonymous with loss of productivity, whereas this condition influences the commitment and credibility of those who seek and provide health care services.

Professional qualification in care for the hospitalized child with chronic cancer pain was a condition that emerged as an intervenient of care quality. In this regard, one research ${ }^{(18)}$ identified significant differences in the level of knowledge of three different groups of health professionals on pain management. In the aforementioned research, doctors were the health professionals who presented the highest level of knowledge on the subject (36.1\%), compared to pharmacists (35.5\%) and nurses (24.1\%). However, in the same study, considering the use of tools in the clinical evaluation of pain, nurses had a higher percentage (92\%), compared to doctors (85\%) and pharmacists (65\%), a fact also observed in the implementation of guidelines, with the following result: nurses (74\%), doctors (60\%), pharmacists (47\%). This finding corroborates the results of a survey ${ }^{(19)}$ conducted in a hospital in Iran, which revealed that most of the oncologists who participated in the study correctly answered less than $80 \%$ of the questions regarding the management of cancer pain. In this 
study, only $13.8 \%$ of the nurses presented training on effective pain management, while $80 \%$ did not receive specific training.

Health professionals characterized excessive collections and lack of communication as limiting conditions for teamwork. The lack of communication among the members of the multiprofessional health staff, associated to the difficulty in performing a collective work, was also pointed out, in an integrative review ${ }^{(14)}$, as a source of interprofessional conflicts in the Pediatric Oncology context. In this sense, communication presents itself as an important condition for the well-being of the child, the family and health professionals. In contrast, when ineffective in caring relationships, it can cause depression, increased anxiety, hopelessness, and decreased quality of life ${ }^{(20)}$.

It should be stressed that great demands can lead to negative impacts on the health of the worker ${ }^{(13)}$, as they may favor their physical and mental illness, jeopardize teamwork and the quality of care provided. The literature ${ }^{(7,21-23)}$ reinforces some of the barriers found in this research and adds others that may limit pain management, such as: morphine prescription problems, family resistance to morphine use, professional belief in the use of opioids, bureaucratic and infrastructure problems, availability of drugs in the unit, lack of formal and continuous education, as well as lack of definition of processes.

The participants of the present study characterized the family member as an intervening condition of the child-professional relationship, since now he acts as a collaborator and, at other times, as a generator of tension in the interactive process. In this regard, a research ${ }^{(24)}$ highlighted the family member, in the hospital context, as an agent facilitating care management by cooperating in the assessment and non-pharmacological management of pain, as well as by notifying the nurse about the child's pain episodes.

However, it is added that many barriers found in the management of pediatric pain are related to the parents, as they exaggerate the pain of their children and thus request painkillers even before the child really needs $i^{(15)}$. In this direction, a research ${ }^{(25)}$ considered $^{(2)}$ family members' reluctance to prescribed medication as a barrier to the adequate management for the hospitalized child's pain. In this respect, it is important to note that such behavior may be related to parental concerns about the side effects of opioids and the possibility of child dependence on this type of medication.

The decisive role of the family in the individual destinies of children is emphasized. Parental personalities are aspects imprinted on children's souls in permanent condition. Thus, in the lens of complexity, it is understood that the family can be configured as both a safe space and a prison for the child. As a dynamic autonomous unit, it can be a source of pathologies and sufferings for the child, but it can also be a center of transmission of joy, love and happiness ${ }^{(8)}$.

On the other hand, it was understood that teamwork and professional qualification are configured as facilitating conditions for the care management for the hospitalized child with chronic cancer pain. Teamwork is influenced by aspects such as trust, motivation, mutual respect, openness to dialogue, norms, organizational culture, worldview, ethics and professional knowledge $^{(26)}$. It is emphasized that a well-developed inter-professional communication facilitates the ability of the health professional to think critically and to understand the values that permeate the relations with the patient who experiences the pain ${ }^{(26)}$.
In teamwork, the complementarity relationship prevails and that of interdependence gains strength, given the multidimensionality of pain and the complexity of hospitalized child. However, it is emphasized that this situation does not cancel out the occurrence of disorders, since in the interdisciplinary dialogue there may be divergences of ideas and opinions that are seen in the lens of complexity as possibilities of negotiation for the establishment of order in the context of disorder.

The dialogue and establishment of a caring relationship between the nursing professional and the hospitalized child with chronic cancer pain were characterized as facilitating conditions of the interactive process, favoring care relationships. A research ${ }^{(27)}$ presented the affective relationship as an important strategy of interaction between the nursing professional and the hospitalized child in chronic condition.

In the perspective of complexity, it is understood that everything that is human involves affectivity. Such an element enables communication in interpersonal relationships, sympathy and empathy, which maximizes the possibility of mutual understanding. Therefore, affectivity is strongly linked to the idea of subject and intersubjectivity, on which rests the most grand, important, rich and ardent part of social life ${ }^{(8)}$

Likewise, playful was considered by the health professionals as a facilitating condition for the care of the hospitalized child with chronic cancer pain, since it favors the performance of procedures, promotes the relaxation of the child and intensifies the interactive process. A research ${ }^{(28)}$ revealed, from the perspective of the nursing team, that playing makes the child less agitated and facilitates the development of care, interaction and communication between the professional and the child.

Regarding the relationship between the nursing professional and the family member, it was identified that empathy emerged as a facilitator of the interactive process, since it enables the professional to understand family suffering. Regarding this condition, research ${ }^{(27)}$ revealed that empathy was also used by the nurse as a strategy for interaction with the family member of the hospitalized child in a chronic condition.

In the perspective of complexity, it is understood that empathy enables the human being to share feelings and meanings constructed in social interactions. However, even though there are complementarity relations in the construction of being, the other and the collective ${ }^{(8)}$, the experience of chronic cancer pain is always singular, subjective and non-transferable. Empathy is a human attitude of understanding that arises in intersubjectivity. Therefore, it emerges from the relationship between subjects who are at the same time similar and different. Thus, empathy arises as a condition that can lead to care relationships, making them more flexible and supportive, thus contributing to the physical and mental well-being of both the health professional as well as the family and the child ${ }^{(28)}$.

\section{Study limitations}

Although the evaluators, in the process of validating the results, have highlighted the rigor of this research regarding the adjustment criterion, since it reflects with confidence the reality experienced by its participants, as well as the criterion of 
understanding, since it is easy to understand for the reader and has internal coherence, it is important to emphasize its limitation regarding the criterion of theoretical generalization, since it presents contextual specificities of a single pediatric setting in the city of Rio de Janeiro, Brazil. However, it should be noted that the conceptual category presented, through new research and theoretical insights, can support contextual variations in order to represent new realities.

\section{Contributions to Nursing}

It is understood that the identification of the intervening conditions and the discussion of their impacts on the quality of care management for the hospitalized child with chronic cancer pain contributed to a diagnosis about the fragilities and potentialities of the investigated context. This movement is necessary to redefine organizational aspects of the setting through effective nursing planning, in which prevention and the search for solutions to the revealed disorders are placed as one of the managerial priorities.

\section{FINAL CONSIDERATIONS}

From the results and in light of the paradigm of complexity, it is emphasized that both order and disorder are necessary conditions to think about the care management for the hospitalized child with chronic cancer pain, given the ability of this dialogic to confer dynamism, flexibility, innovations and advances in social relations established in the work process.

In this sense, it was understood that the relatives of hospitalized children with chronic cancer pain were perceived as intervening conditions of care management due to their important influence in the construction of the meaning and behavior of the child throughout the hospitalization process. As limiting conditions for care management, they are: deficits of human resources and materials, absenteeism, ineffective teamwork, professional relocation and insufficient professional qualification. On the other hand, they were presented as facilitating conditions: adequate professional knowledge, effective teamwork, dialogue, empathy, playful and affective relationship with the child.

\section{REFERENCES}

1. Olagunjun AT, Sarimiye FO, Olagunju TO, Habeebu MYM, Aina OF. Child's symptom burden and depressive symptoms among caregivers of children with cancers: an argument for early integration of pediatric palliative care. Ann Palliat Med [Internet]. 2016 [cited 2017 Fev 22]; 5(3):157-165. Available from: https://www.ncbi.nlm.nih.gov/pubmed/27199271

2. Cederberg JT, Strandskov SW, Dahl J, LjungmanG. Parents relationship to pain during children's cancer treatment - a preliminary validation of the pain flexibility scale for parents. J Pain Res [Internet]. 2017 [cited 2017 Jun 09]; 3(10):507-14. Available from: https://www.ncbi.nlm.nih. gov/pubmed/28424558

3. Rodrigues AJ, Bushatsky M, Viaro WD. Palliative care in children with cancer: integrative review. Rev enferm UFPE on line [Internet]. 2015 [cited 2017 Fev 22]; 9(2):718-30. Available from: http://www.revista.ufpe.br/revistaenfermagem/index.php/revista/article/view/7129/pdf_7201 pdf

4. World Health Organization. Persisting pain in children package: WHO guidelines on the pharmacological treatment of persisting pain in children with medical illnesses [Internet]. Geneva:WHO; 2012 [cited 2017 Fev 22]. 172 p. Available from: http://whqlibdoc.who.int/ publications/2012/9789241548120_Guidelines.pdf

5. American Pain Society. Assessment and management of children with chronic pain: a position statement from the American Pain Society [Internet]. Chicago (IL): APS; 2012 [cited 2017 Fev 22]. 4 p. Available from: http://www.americanpainsociety.org/uploads/pdfs/aps12-pcp.pdf

6. Fortier MA, Wahi A, Bruce C, Maurer EL, Stevenson R. Pain Management at home in children with cancer: a daily diary study. Pediatr Blood Cancer [Internet]. 2014 [cited 2017 Fev 22]; 61(6):1029-33. Available from: https://www.ncbi.nlm.nih.gov/pubmed/24376073

7. Schute C. The challenges of cancer pain assessment and management. Ulster Med J [Internet]. 2013 [cited 2017 Fev 22]; 82(1):40-2. Available from: https://www.ncbi.nlm.nih.gov/pmc/articles/PMC3632849/

8. Morin E. O método 5: a humanidade da humanidade. 5a ed. Porto Alegre (RS): Sulina; 2012. 186 p.

9. Jibb LA, Nathan PC, Stevens BJ, Seto E, Cafazzo J, Stephens S, et al. Psychological and physical interventions for the management of cancerrelated pain in pediatric and young adults patients: an integrative review. Oncol Nurs Forum [Internet]. 2015 [cited 2017 Fev 22]; 42(6):33957. Available from: https://www.ncbi.nlm.nih.gov/pubmed/26488841

10. Thompson LA, Meinert E, baker K. Chronic pain management as a barrier to pediatric palliative care. Am J Hosp Palliat Care [Internet]. 2013 [cited 2017 Fev 22]; 30(8):764-7. Available from: https://www.ncbi.nlm.nih.gov/pubmed/23329083

11. Batalha LMC, Fernandes AM, Campos C, Gonçalves AMPMPC. Pain assessment in children with cancer: a systematic review. J Nurs Ref [Internet]. 2015 [cited 2017 Fev 22]; 4(5):119-127. Available from: http://dx.doi.org/10.12707/RIV14013

12. Strauss AL, Corbin J. Pesquisa qualitativa: técnicas e procedimentos para o desenvolvimento de teoria fundamentada. 2a ed. Porto Alegre (RS): Artmed; 2008. 288 p.

13. Silva TP, Silva IR, Leite JL. Interactions in the management of nursing care to hospitalized children with chronic conditions. Texto Contexto Enferm [Internet]. 2016 [cited 2017 Fev 12]; 25(2):e1980015. Available from: http://dx.doi.org/10.1590/0104-07072016001980015

14. Marques FRB, Ferreira MCVS, Duarte AM, Balieiro DMFG, Mandetta MA. Nature and source of conflits of relationships in the context of pediatric oncology: an integrative literature review. Cienc Cuid Saude [internet]. 2015 [cited 2017 Fev 12]; 14(2):1184-1193. Available from: file:///C:/Users/User/Downloads/25247-120573-1-PB\%20(1).pdf 
15. Twycross A. Nurses' views about the barriers and facilitators to effective management of pediatric pain. Pain Mang Nurs [Internet]. 2013 [cited 2017 Fev 22]; 14(4):164-72. Available from: https://www.ncbi.nlm.nih.gov/pubmed/24315269

16. Joan S. A proposed model of the effective management of children's pain. Pain Manag Nurs [Internet]. 2015 [cited 2017 fev 22]; 16(4):570-8. Available from: https://www.ncbi.nlm.nih.gov/pubmed/26256220

17. Ruiz PBO, Perroca MG, Jericó MC. People management indicator: assessment of resignations and turnover rate of nursing personnel. Rev Enferm UFPE on line [Internet]. 2015 [cited 2017 Fev 22]; 9(2):643-50. Available from: http://www.revista.ufpe.br/revistaenfermagem/index. $\mathrm{php} /$ revista/article/view/6712/pdf_7163

18. Nuserir K, Kassab M, Almomani B. healthcare providers' knowledge and current practice of pain assessment and management: how much progress have we made? Pain Res Treat [Internet]. 2016 [cited 2017 Jun 09]; 2016(2016):8432973. Available from: http://dx.doi. org/10.1155/2016/8432973

19. Shahdad S, Shiryyazdi SM, Shiryazdi SA, Arjomandi A, Haghighi F, Vakili FM. Mostafaie N Oncology nurses knowledge and attitudes cancer pain management. Asian Pac J Cancer Prev [Internet]. 2015 [cited 2017 Fev 22]; 16(17):7501-7506. Available from: http://dx.doi.org/10.7314/ APJCP.2015.16.17.7501

20. Citak EA, Toruner EK, Gunes NB. Exploring communication difficulties in pediatric hematology: oncology nurses. Asian Pac J Cancer Prev [Internet]. 2013 [cited 2017 Fev 22]; 14(9):5477-82. Available from: https://www.ncbi.nlm.nih.gov/pubmed/24175845

21. Yaho A, Coze C, Traoré F, André N, Moreira C, Pondy A. [Managing pain in children with cancer in Africa: a survey from the French-African Pediatric Oncology Group]. Arch Pediatr [Internet]. 2013 [cited 2017 Fev 22]; 20(3):257-64. Available from: https://www.ncbi.nlm.nih.gov/ pubmed/23391447 French

22. Lebaron V, Beck SL, Maurer M, Black F, Palat G. An ethnographic study of barriers to cancer pain management and opioid availability in India. Oncologist [Internet]. 2014 [cited 2017 Fev 22]; 19(5):515-22. Available from: https://www.ncbi.nlm.nih.gov/pubmed/24755460

23. Arslan D, koca T, Akar E, Tural D, Ozdogan M. Cancer pain prevalence and its management. Asian Pac J Cancer Prev [Internet]. 2014 [cited 2017 Fev 22]; 15(20):8557-62. Available from: https://www.ncbi.nlm.nih.gov/pubmed/25374167

24. Aziznejadroshan P, alhani F, Mohammadi E. Experiences of Iranian nurses on the facilitators of pain management in children: a qualitative study. Pain Res Treat [Internet]. 2016 [cited 2017 jun 09]; 2016(6):1-7. Available from: https://www.ncbi.nlm.nih.gov/pubmed/27123342

25. Czarnecki ML, Salamon KS, Thompson JJ, Hainsworth KR. Do barriers to pediatric pain management as perceived by nurses change over time? Pain Manag Nurs [Internet]. 2014 [cited 2017 Fev 22]; 15(1):292-305. Available from: https://www.ncbi.nlm.nih.gov/ pubmed/23433700

26. Unné A, rosengren K. Staff Experience of pain management: in inprovement in palliative care. Pharmacy [Internet]. 2013 [cited 2017 Jun 09]; 1(2):119-36. Available from: http://www.mdpi.com/2226-4787/1/2/119

27. Silva TP, Silva MM, Alcantara LM, Silva IR, Leite JL. Estableshing action/interaction strategies for care delivery to hospitalized children with chronic conditions. Esc Anna Nery Rev Enferm [Internet]. 2015 [cited 2017 Fev 22]; 19(2):279-85. Available from: //dx.doi. org/10.5935/1414-8145.20150037

28. Terezam R, reis-Queiroz J, Hoga LAK. The importance of empathy in helth and nursing care. Rev Bras Enferm [Internet]. 2017 [cited 2017 Jun 09]; 70(3):669-70. Available from: http://www.scielo.br/pdf/reben/v70n3/0034-7167-reben-70-03-0669.pdf Portuguese 